ISSN 1392-3196 / e-ISSN 2335-8947

Zemdirbyste-Agriculture, vol. 103, No. 3 (2016), p. 289-296

DOI 10.13080/z-a.2016.103.037

\title{
The effect of cationic and nonionic surfactants on the efficacy of ALS-inhibitor herbicides against Avena sterilis
}

\author{
Akbar ALIVERDI ${ }^{1}$, Hossein HAMMAMI ${ }^{2}$ \\ ${ }^{1}$ Department of Agronomy and Plant Breeding, Bu-Ali Sina University \\ Hamedan, 6517838695 Hamadan, I.R. Iran \\ E-mail: a.aliverdi@basu.ac.ir \\ ${ }^{2}$ Department of Agronomy and Plant Breeding, University of Birjand \\ South Khorasan, A78 97175615 Birjand, I.R. Iran
}

\begin{abstract}
A major challenge is selection of a suitable surfactant for a given herbicide. A series of dose-response experiments were conducted during 2013 at Ferdowsi University of Mashhad, Iran under greenhouse and outdoor conditions to determine whether the efficacy of four acetolactate synthase (ALS)-inhibitor herbicides on Avena sterilis could be improved by adding two surfactants at two concentrations. Both surfactants were effective at lowering the surface tension of all herbicide solutions with the nonionic surfactant being more effective than the cationic one. According to effective dose (ED)-values, the ranking of the ALS-inhibitor herbicides to control A. sterilis was: sulfosulfuron $>$ mesosulfuron-methyl + iodosulfuron-methyl-sodium with safener mefenpyr $>$ mesosulfuronmethyl + iodosulfuron-methyl-sodium with safener mefenpyr-diethyl $>$ metsulfuron-methyl + sulfosulfuron. The EDs of all herbicides decreased when applied with surfactants. Cationic surfactant had a greater ability to enhance the efficacy of the tested herbicides than nonionic surfactant.
\end{abstract}

Key words: dose-response, herbicide efficacy, sulfonylurea herbicides.

\section{Introduction}

The genus of Avena contains several species often infesting small grain cereal crops all over the world. An economic threshold of 5.23 plants $\mathrm{m}^{-2}$ for Avena spp. was estimated in wheat populations (Gerkhloo et al., 2007). The Avena sterilis spp. ludoviciana Durieu. (syn: A. persica Steud.) has infested excessively many wheat and barley agro-ecosystems. Yield of wheat (Triticum aestivum L.) was reduced up to $18 \%$ and $44 \%$ at the density of 20 and $61 \mathrm{~A}$. sterilis $\mathrm{m}^{-2}$, respectively (Montazeri, 2007; Hesammi, 2011). A. sterilis is a serious annual weed reproducing by seeds which belongs to the family Poaceae native to Europe and Asia. It can produce 3-5 tillers and has leaf blade twisted counter clockwise. Seeds usually ripen earlier than small grain cereal crops and drop to the ground before time to harvest cultivated crops (Dickinson, Royer, 2014).

During the past two decades, clodinafoppropargyl, diclofop-methyl and fenoxaprop-P-ethyl, all belonging to the acetyl coenzyme A carboxylase (ACCase) inhibitor herbicide group were authorized to control A. sterilis in wheat and barley agro-ecosystems (Chhokar et al., 2012). These graminicides were widely used due to their high effectiveness (Zand et al., 2007). During 1995-2005, clodinafop-propargyl, fenoxapropP-ethyl and diclofop-methyl were applied in Iran up to 3653, 2379 and 2339 tons, respectively (Deihimfard et al., 2007). Due to a continuous high selection pressure, herbicide resistance to ACCase inhibitors developed in A. sterilis populations (Kashani et al., 2007). Accordingly, these observations proved the necessity of replacement of ACCase-inhibiting herbicides with other herbicide modes of action. The sulfonylurea herbicides were assessed (Zand et al., 2010) as good alternatives for this purpose due to their ability to control a broad spectrum of monocot and dicot weeds, combined with their low application rate and good environmental profile (Green, 2007). Therefore, during 2006-2010, four acetolactate synthase (ALS) inhibitors including the herbicides of sulfosulfuron (1), mesosulfuron-methyl + iodosulfuron-methyl-sodium with safener mefenpyr (2), mesosulfuron-methyl + iodosulfuron-methyl-sodium with safener mefenpyr-diethyl (3) and metsulfuronmethyl + sulfosulfuron (4) were authorized for selective control of $A$. sterilis.

The efficacy of herbicides can be enhanced using surfactants (Knezevic et al., 2009; Loken, HattermanValenti, 2013; Gitsopoulos et al., 2014). Enhancement of herbicidal activity by surfactants may be related to improving the dose transfer process (absorption) of active ingredient on weed leaves (McCullough, Hart, 2009). In this process, surface tension of the droplet is a key factor to be retained and spread on leaves (Stagnari 
et al., 2007). The surfactants reduce the surface tension of spray solution, leading to both the production of smaller droplets in the atomization process and the promotion of adhesion between spray droplets with leaf surface. Although enhancement of herbicidal activity can allow for reducing herbicide dose (Kudsk, 2008), it is the major cause for herbicide failures/weed escapes and enhanced selection pressure for resistance development (Green, 2007). One of the risks of many ALS-inhibiting herbicides is their long-term soil residual activity, resulting in a long selection pressure towards herbicide resistance (Rao, 2015).

Although the performance of foliar applied herbicides is greatly affected by surfactants, not all surfactants have a synergistic effect with herbicides (Kammler et al., 2010). Rashed-Mohassel et al. (2010) evidenced that various surfactants carry out different functions to various herbicides on different weed species. Besides, each surfactant is not able to increase absorption of all kinds of herbicides. The objectives of the present study were to determine the effect of nonionic and cationic surfactants on the activity of four ALS-inhibiting herbicides and the possibility of reducing the dose in order to achieve the goals mentioned above including identifying a proper indicator to select a suitable surfactant.

\section{Materials and methods}

Dose-response study. A pot experiment was repeated twice during 2013 at Ferdowsi University of Mashhad, Iran; once in greenhouse conditions and once in outdoor conditions (the pots were taken out). Seeds of Avena sterilis were collected from farm fields of Mashhad Agricultural and Natural Resources Research Center, Iran (36 ${ }^{\circ} 15^{\prime \prime} \mathrm{N}, 5^{\circ} 28^{\prime \prime}$ E, $985 \mathrm{~m}$ a.s.1.). To break dormancy, seeds were de-hulled and placed in $11 \mathrm{~cm}$ diameter Petri dishes on the surface of a single layer of Whatman No. 1 filter paper. Then, $10 \mathrm{ml}$ of $0.2 \% \mathrm{KNO}_{3}$ solution were added to each Petri dish and the seeds were incubated for $48 \mathrm{~h}$ at $4-5^{\circ} \mathrm{C}$ in the dark (Rashed-Mohassel et al., 2011). Seeds were sown in potting trays $(3 \times 3 \times 5 \mathrm{~cm})$ filled with moistened peat. One week after sowing, when the seedlings had one leaf, they were transplanted into 2 L black plastic pots $(14 \mathrm{~cm}$ diameter top, $9 \mathrm{~cm}$ diameter base and $16 \mathrm{~cm}$ depth) filled with a mixture of sand, clay loam soil, and peat (1:1:1 v:v:v). The plants were subwatered as required, thinned from ten to five per pot at the two-leaf stage and fertilized once with $40 \mathrm{ml}$ of a watersoluble N:P:K (20:20:20) fertilizer at a concentration of $3 \mathrm{~g} \mathrm{~L}^{-1}$ drinking water.

Four formulations of herbicides at six concentrations were used against $A$. sterilis. The concentrations of each herbicide tested are indicated in the first column of Tables 1 and 2 . These doses consisted of $0,12.5,25,50,75$ and $100 \%$ of the recommended dose, respectively. Each of these doses was applied alone or with the surfactants of nonionic and cationic surfactants at two concentrations. There were four replications of each treatment. The drinking water was used as spray carrier with an acceptable quality level of $\mathrm{Na}^{+}=113.4 \mathrm{mg} \mathrm{L}^{-1}, \mathrm{Ca}^{+2}$ $=27.9 \mathrm{mg} \mathrm{L}^{-1}, \mathrm{Mg}^{+2}=8.3 \mathrm{mg} \mathrm{L}^{-1}, \mathrm{HCO}_{3}^{-}=199.3 \mathrm{mg} \mathrm{L}^{-1}$, $\mathrm{SO}_{4}^{-}=188.0 \mathrm{mg} \mathrm{L}^{-1}$, electrical conductivity $=1012 \mu \mathrm{mho}$ $\mathrm{cm}^{-1}$ and $\mathrm{pH}=7.6$. The drinking water used in this study had hardness $\sim 70 \mathrm{mg} \mathrm{L}^{-1}$ of $\mathrm{CaCO}_{3}$. According to McDougall (2012), water with this quality can be classified into the class of moderately soft (50-75; hardness expressed as mg $\mathrm{L}^{-1}$ of $\mathrm{CaCO}_{3}$ ). The spray treatments were applied at the four-leaf stage using a calibrated moving boom sprayer Matabi 121030 Super Agro 20 L (Agratech Services, UK), equipped with an 8002 flat fan nozzle tip delivering $200 \mathrm{~L}$ $\mathrm{ha}^{-1}$ at a pressure of $200 \mathrm{kPa}$. The spray conditions in the greenhouse were a simulation of the spray conditions in the field. Therefore, here the mentioned nozzle was applied. Four weeks after spraying, aboveground biomass from each pot was collected and weighed after oven-drying at $75^{\circ} \mathrm{C}$ for $48 \mathrm{~h}$.

Dry weight data were subjected to a non-linear regression analysis using the following logarithmic logistic dose-response model described by Kudsk and Mathiassen (2007):

$$
Y=C+\{D-C / 1+\exp [B(\log X-\log E D)]\}(1),
$$

where $Y$ is the response (e.g., dry weight), $C-$ the lower limit, $D$ - the upper limit, $B$ - the slope of the curve, $X-$ the herbicide dose and effective dose (ED) - the required dose of herbicide to give a reduction of $50 \%\left(\mathrm{ED}_{50}\right)$ or $90 \%\left(\mathrm{ED}_{90}\right)$ between the upper and lower limits. The upper limit (D) corresponds to the response of the untreated control. All data were checked for normality through tests of the Shapiro-Wilk statistic. The nonlinear regression analysis of dose-response curves were determined utilizing the $\mathrm{R}$ software and were performed separately for each herbicide.

Static surface tension study. A capillary rise technique was used to measure the static surface tension of aqueous solutions (Vanhanen et al., 2008), using the following equation:

$$
\gamma=0.5 \rho g r(h+(r / 3))
$$

where $\gamma$ is the surface tension $\left(\mathrm{Nm}^{-1}\right)$ which was converted to $\mathrm{mNm}^{-1}$ for analysis, $\rho$ is the density of liquid $\left(\mathrm{kg} \mathrm{m}^{-3}\right), g-$ the acceleration due to gravity which is $9.8 \mathrm{~ms}^{-2}, r$ - the inner radius of the glass capillary tube (m) which was $0.5 \mathrm{~mm}$, and $h$ - the capillary rise (m). The static surface tension of aqueous solution of cationic and nonionic surfactant alone was measured as reported by Aliverdi et al. (2009). The herbicides Nos. 1, 2, 3 and 4 (Tables 1 and 2) were prepared at concentrations corresponding to the maximum doses applied (a.i. 20, 24, 30 and $45 \mathrm{~g}$ ) in $200 \mathrm{~L}$ drinking water ha ${ }^{-1}$, respectively. Frigate $^{\circledR}$ (ISK Biosciences Corp., England) as a cationic surfactant (81.2\% polyoxyethylene tallow amines), and Citogate $^{\circledR}$ (ZarNegaranPars, Iran) as a non-ionic surfactant - $100 \%$ alkylarylpolyglycol ether were applied. For each herbicide, a trial was conducted as a completely randomized design with three replications for each treatment. The treatments included each herbicide at concentrations corresponding to the maximum doses (as controls) with and without each of the nonionic 
and cationic surfactants at $0.1 \%$ and $0.2 \%(\mathrm{v} / \mathrm{v})$. Each solution was prepared twice and three measurements were conducted on each solution. The results were combined into one analysis as similar results were detected in both trials. Data (except those of drinking water) were subjected to an $A N O V A$ and treatment means were separated using Tukey's test at the 0.05 probability level.

\section{Results}

Static surface tension. The drinking water surface tension was recorded $68.61 \mathrm{mN} \mathrm{m}^{-1}$. All formulations of herbicides significantly decreased surface tension of drinking water (Fig. 1). The surface tension of drinking water was reduced up to $9.58,8.11$, 21.23 and $11.03 \%$ by adding the herbicides Nos. 1, 2, 3 and 4, respectively. Both surfactants were effective at lowering the surface tension of all spray solutions; however, nonionic surfactant was more effective than cationic surfactant (Fig. 1). In the case of herbicides Nos. 1 and 4, the surface tension spray solution was significantly decreased with increasing concentration of nonionic surfactant; but, it was insignificantly decreased with increasing concentration of cationic one. In the case of herbicides Nos. 2 and 3, the static surface tension of other spray solution was significantly decreased with increasing concentration of both surfactants.

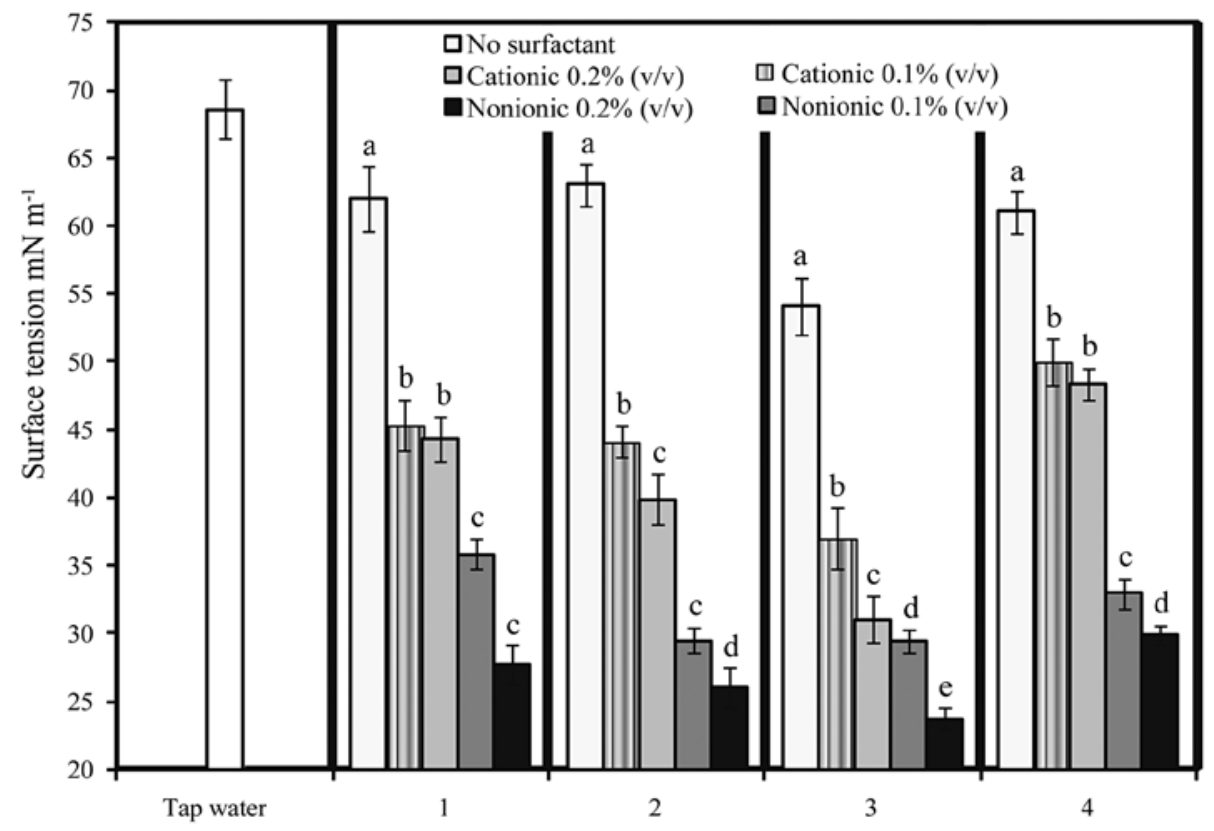

Notes. The vertical lines on the bars show the standard errors. Within each herbicide trial, the surface tension of solutions classes differ $(P \leq 0.05)$ when followed by a unique letter according to ANOVA-Tukey test. 1 - sulfosulfuron, 2 - mesosulfuron-methyl + iodosulfuron-methyl-sodium with safener mefenpyr, 3 - mesosulfuron-methyl + iodosulfuron-methyl-sodium with safener mefenpyr-diethyl, 4 - metsulfuron-methyl + sulfosulfuron.

Figure 1. Effect of cationic and nonionic surfactants on surface tension of acetolactate synthase (ALS)-inhibitor herbicides

Dose-response experiments. The dose response curves for herbicides Nos. 1, 2, 3 and 4 in greenhouse experiment indicated an $\mathrm{ED}_{50}$ of 8.94, 11.24, 12.81 and $13.13 \mathrm{~g} \mathrm{ha}^{-1}$ a.i., respectively. In outdoor experiment, $\mathrm{ED}_{50}$ parameter values were higher $-13.11,17.31,20.39$ and $27.86 \mathrm{~g} \mathrm{ha}^{-1}$ a.i., respectively (Tables 1 and 2). These findings suggest two points; firstly, in equivalent doses herbicide No. 4 was less effective than the other herbicides. The ranking of the performance on A. sterilis of the applied herbicides was $1>2>3>4$. This result was also confirmed by the $\mathrm{ED}_{90}$ parameters. In outdoor experiment, the estimated $\mathrm{ED}_{90}$ value for herbicide No. 3 was higher than the maximum applied dose.

Dose-response curves showed that both surfactants enhanced the activity of all tested herbicides (Fig. 2). Because the dose-response curves of original herbicide formulations were shifted to the left by adding of the surfactants. This consequence depends on the concentration of surfactants. When the surfactants were added to the tested herbicides, the values of $\mathrm{ED}_{50}$ and $\mathrm{ED}_{90}$ parameters decreased (Tables 1 and 2). Apart from the above mentioned result, increased effectiveness of the tested herbicides depended upon the concentration of both cationic and nonionic surfactants.

In the case of nonionic surfactant, the $\mathrm{ED}_{50}$ values of four herbicides decreased with increasing surfactant concentration both in greenhouse and outdoor pot experiments. Although in the case of cationic surfactant behaviour, some differences between the results of greenhouse and outdoor experiments were observed, there are no justifying explanations for such differences. In greenhouse experiments, there was a significant difference between the applied concentrations 

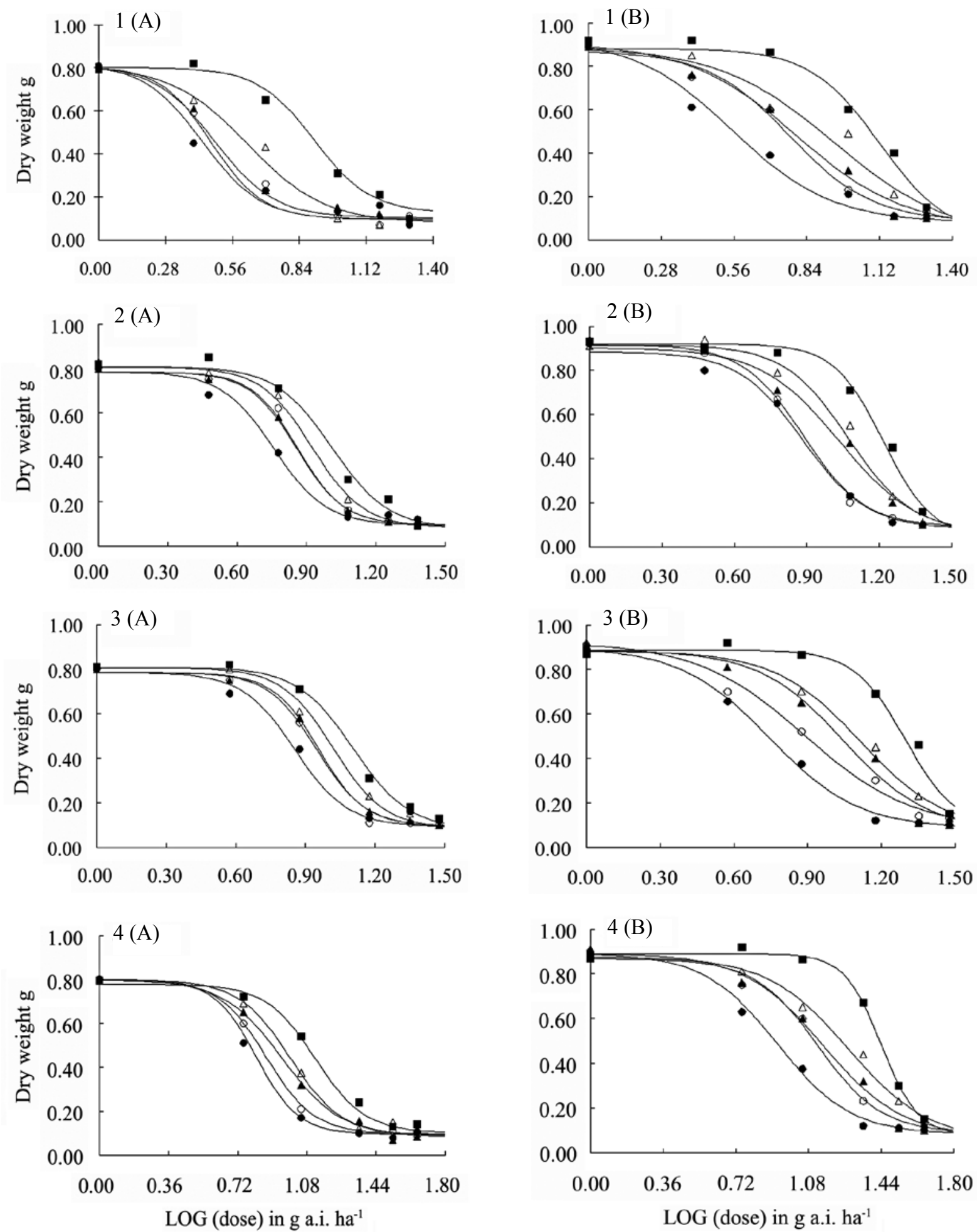

1 - sulfosulfuron, 2 - mesosulfuron-methyl + iodosulfuron-methyl-sodium with safener mefenpyr, 3 - mesosulfuron-methyl + iodosulfuron-methyl-sodium with safener mefenpyr-diethyl, or 4 - metsulfuron-methyl + sulfosulfuron alone (a) and in mixture with cationic surfactant at concentrations of $0.1 \%(\circ)$ or $0.2 \%(\bullet)$ or nonionic surfactant at concentrations of $0.1 \%(\Delta)$ or $0.2 \%(\boldsymbol{\Delta})$ on the shoot dry weight of Avena sterilis; experiments in greenhouse (A) and outdoor conditions (B); LOG - logarithm

Figure 2. Dose-response curves of cationic and nonionic surfactants of acetolactate synthase (ALS)-inhibitor herbicides

of cationic surfactant in enhancing the effectiveness of herbicides Nos. 2 and 3 against $A$. sterilis. In contrast, such influence on herbicide No. 1 was not observed (Table 1). In outdoor experiments, the efficacy of herbicide No. 2 was not improved by increasing the concentration of cationic surfactant (Table 2). Generally, increasing the concentration of nonionic surfactant had more effect on the efficacy of the tested herbicide formulations than increasing the concentration of cationic surfactant (Tables 1 and 2). 
Table 1. Effect of surfactants and their concentrations on effective doses $\mathrm{ED}_{50}$ and $\mathrm{ED}_{90}$ of four herbicides on Avena sterilis in greenhouse conditions

\begin{tabular}{|c|c|c|c|c|c|c|}
\hline No. & $\begin{array}{l}\text { Herbicide (formulation name) } \\
\text { concentrations tested }\end{array}$ & Surfactant & $\begin{array}{c}\text { Concentration } \\
\% \mathrm{v} / \mathrm{v}\end{array}$ & $\begin{array}{l}\mathrm{ED}_{50} \\
\mathrm{~g} \mathrm{ha}^{-1} \text { a.i. }\end{array}$ & $\begin{array}{l}\mathrm{ED}_{90} \\
\mathrm{~g} \mathrm{ha}^{-1} \text { a.i. }\end{array}$ & $R$ \\
\hline \multirow[t]{5}{*}{1.} & \multirow{5}{*}{$\begin{array}{l}\text { Sulfosulfuron (Apyrous }{ }^{\circledR} \text { WG } 75 \% \text { ) } \\
0,2.5,5,10,15 \text { and } 20 \mathrm{~g} \mathrm{~h}^{-1} \text { a.i. }\end{array}$} & none & - & $8.94(0.71)$ & $13.81(0.38)$ & 1.00 \\
\hline & & \multirow{2}{*}{ nonionic } & 0.1 & $4.60(0.52)$ & $8.66(0.41)$ & $1.94(0.18)$ \\
\hline & & & 0.2 & $3.17(0.44)$ & $6.52(0.33)$ & $2.81(0.08)$ \\
\hline & & \multirow{2}{*}{ cationic } & 0.1 & $2.98(0.43)$ & $5.09(0.19)$ & $3.00(0.22)$ \\
\hline & & & 0.2 & $2.74(0.55)$ & $4.99(0.12)$ & $3.25(0.41)$ \\
\hline \multirow[t]{5}{*}{2.} & \multirow{5}{*}{$\begin{array}{l}\text { Mesosulfuron-methyl + iodosulfuron- } \\
\text { methyl-sodium with safener mefenpyr } \\
\left(\text { Chevalier }{ }^{\circledR} \text { WG } 3 \%+3 \%\right) \\
0,3,6,12,18 \text { and } 24 \mathrm{~g} \mathrm{~h}^{-1} \text { a.i. }\end{array}$} & none & - & $11.24(0.82)$ & $18.31(0.11)$ & 1.00 \\
\hline & & \multirow{2}{*}{ nonionic } & 0.1 & $8.32(0.45)$ & $13.94(0.09)$ & $1.35(0.21)$ \\
\hline & & & 0.2 & $7.17(0.44)$ & $11.75(0.14)$ & $1.56(0.20)$ \\
\hline & & \multirow{2}{*}{ cationic } & 0.1 & $7.09(0.37)$ & $11.76(0.08)$ & $1.58(0.25)$ \\
\hline & & & 0.2 & $5.63(0.51)$ & $9.85(0.23)$ & $1.99(0.11)$ \\
\hline \multirow[t]{5}{*}{3.} & \multirow{5}{*}{$\begin{array}{l}\text { Mesosulfuron-methyl + iodosulfuron- } \\
\text { methyl-sodium with safener mefenpyr- } \\
\text { diethyl (Atlantis }{ }^{\circledR} \text { OD } 1 \%+0.2 \% \text { ) } \\
0,3.75,7.5,15,22.5 \text { and } 30 \mathrm{~g} \mathrm{~h}^{-1} \text { a.i. }\end{array}$} & none & - & $12.81(1.01)$ & $22.88(0.18)$ & 1.00 \\
\hline & & \multirow{2}{*}{ nonionic } & 0.1 & $10.41(0.55)$ & $17.42(0.22)$ & $1.23(0.06)$ \\
\hline & & & 0.2 & $9.06(0.32)$ & $14.69(0.31)$ & $1.41(0.08)$ \\
\hline & & \multirow{2}{*}{ cationic } & 0.1 & $8.75(0.35)$ & $14.71(0.23)$ & $1.46(0.29)$ \\
\hline & & & 0.2 & $5.04(0.48)$ & $12.32(0.12)$ & $2.54(0.15)$ \\
\hline \multirow[t]{5}{*}{4.} & \multirow{5}{*}{$\begin{array}{l}\text { Metsulfuron-methyl + sulfosulfuron } \\
\left(\text { Total }{ }^{\circledR} \text { WG } 5 \%+75 \%\right) \\
0,5.625,11.25,22.5,33.75 \\
\text { and } 45 \mathrm{~g} \mathrm{~h}^{-1} \text { a.i. }\end{array}$} & none & - & $13.13(0.91)$ & $25.56(0.41)$ & 1.00 \\
\hline & & \multirow{2}{*}{ nonionic } & 0.1 & $9.71(0.54)$ & $18.57(0.13)$ & $1.35(0.09)$ \\
\hline & & & 0.2 & $7.01(0.26)$ & $19.96(0.23)$ & $1.87(0.11)$ \\
\hline & & \multirow{2}{*}{ cationic } & 0.1 & $6.34(0.72)$ & $13.67(0.12)$ & $2.07(0.23)$ \\
\hline & & & 0.2 & $5.57(0.56)$ & $11.65(0.11)$ & $2.35(0.05)$ \\
\hline
\end{tabular}

Notes. Data are expressed as the means. Standard errors are in parentheses. $R$ is the relative potency at $\mathrm{ED}_{50}$, indicates the ratio of the doses of herbicide without surfactant $(R=1.00)$ and with surfactant giving the same effect, $R=\mathrm{ED}_{50}$ without surfactant $/ \mathrm{ED}_{50}$ with surfactant, showing horizontal displacement between curves.

Table 2. Effect of surfactants and their concentrations on effective doses $\mathrm{ED}_{50}$ and $\mathrm{ED}_{90}$ of four herbicides on Avena sterilis in outdoor conditions

\begin{tabular}{|c|c|c|c|c|c|c|}
\hline No. & $\begin{array}{l}\text { Herbicide (formulation name) } \\
\text { concentrations tested }\end{array}$ & Surfactant & $\begin{array}{l}\text { Concentration } \\
\% \mathrm{v} / \mathrm{v}\end{array}$ & $\begin{array}{l}\mathrm{ED}_{50} \\
\mathrm{~g} \mathrm{ha}^{-1} \text { a.i. }\end{array}$ & $\begin{array}{l}\mathrm{ED}_{90} \\
\mathrm{~g} \mathrm{ha}^{-1} \text { a.i. }\end{array}$ & $R$ \\
\hline \multirow[t]{5}{*}{1.} & \multirow{5}{*}{$\begin{array}{l}\text { Sulfosulfuron (Apyrous }{ }^{\circledR} \text { WG } 75 \% \text { ) } \\
0,2.5,5,10,15 \text { and } 20 \mathrm{~g} \mathrm{~h}^{-1} \text { a.i. }\end{array}$} & none & - & $13.11(0.82)$ & $21.16(0.51)$ & 1.00 \\
\hline & & \multirow{2}{*}{ nonionic } & 0.1 & $7.81(0.73)$ & $17.68(0.46)$ & $1.67(0.14)$ \\
\hline & & & 0.2 & $5.90(0.55)$ & $13.99(0.43)$ & $2.22(0.27)$ \\
\hline & & \multirow{2}{*}{ cationic } & 0.1 & $5.66(0.16)$ & $11.89(0.49)$ & $2.31(0.04)$ \\
\hline & & & 0.2 & $3.65(0.55)$ & $8.69(0.35)$ & $3.59(0.22)$ \\
\hline \multirow[t]{5}{*}{2.} & \multirow{5}{*}{$\begin{array}{l}\text { Mesosulfuron-methyl + iodosulfuron- } \\
\text { methyl-sodium with safener mefenpyr } \\
\text { (Chevalier® WG } 3 \%+3 \%) \\
0,3,6,12,18 \text { and } 24 \mathrm{~g} \mathrm{~h}^{-1} \text { a.i. }\end{array}$} & none & - & $17.30(1.02)$ & $24.01(0.37)$ & 1.00 \\
\hline & & \multirow{2}{*}{ nonionic } & 0.1 & $12.35(0.56)$ & $20.69(0.11)$ & $1.40(0.23)$ \\
\hline & & & 0.2 & $10.07(0.88)$ & $20.70(0.10)$ & $1.71(0.07)$ \\
\hline & & \multirow{2}{*}{ cationic } & 0.1 & $7.61(0.41)$ & $14.12(0.26)$ & $2.27(0.10)$ \\
\hline & & & 0.2 & $7.34(0.55)$ & $17.68(0.08)$ & $2.36(0.18)$ \\
\hline \multirow[t]{5}{*}{3.} & \multirow{5}{*}{$\begin{array}{l}\text { Mesosulfuron-methyl + iodosulfuron- } \\
\text { methyl-sodium with safener mefenpyr- } \\
\text { diethyl (Atlantis }{ }^{\circledR} \text { OD } 1 \%+0.2 \% \text { ) } \\
0,3.75,7.5,15,22.5 \text { and } 30 \mathrm{~g} \mathrm{~h}^{-1} \text { a.i. }\end{array}$} & none & - & $20.39(0.30)$ & $>30$ & 1.00 \\
\hline & & \multirow{2}{*}{ nonionic } & 0.1 & $12.17(0.77)$ & $27.13(0.22)$ & $1.67(0.23)$ \\
\hline & & & 0.2 & $10.46(0.48)$ & $22.55(0.17)$ & $1.94(0.12)$ \\
\hline & & \multirow{2}{*}{ cationic } & 0.1 & $7.58(0.51)$ & $20.38(0.13)$ & $2.68(0.14)$ \\
\hline & & & 0.2 & $5.51(0.23)$ & $12.93(0.21)$ & $3.70(0.19)$ \\
\hline \multirow[t]{5}{*}{4.} & \multirow{5}{*}{$\begin{array}{l}\text { Metsulfuron-methyl + sulfosulfuron } \\
\left(\text { Total }{ }^{\circledR} \text { WG } 5 \%+75 \%\right) \\
0,5.625,11.25,22.5,33.75 \\
\text { and } 45 \mathrm{~g} \mathrm{~h}^{-1} \text { a.i. }\end{array}$} & none & - & $27.86(0.90)$ & $43.57(0.42)$ & 1.00 \\
\hline & & \multirow{2}{*}{ nonionic } & 0.1 & $17.48(0.23)$ & $40.17(0.33)$ & $1.59(0.17)$ \\
\hline & & & 0.2 & $13.27(0.95)$ & $31.39(0.35)$ & $2.09(0.15)$ \\
\hline & & \multirow{2}{*}{ cationic } & 0.1 & $12.72(0.66)$ & $26.77(0.29)$ & $2.18(0.18)$ \\
\hline & & & 0.2 & $8.27(0.87)$ & $19.31(0.11)$ & $3.36(0.26)$ \\
\hline
\end{tabular}

Notes. Data are expressed as the means. Standard errors are in parentheses. $R$ is the relative potency at $\mathrm{ED}_{50}$, indicates the ratio of the doses of herbicide without surfactant $(R=1.00)$ and with surfactant giving the same effect, $R=\mathrm{ED}_{50}$ without surfactant $/ \mathrm{ED}_{50}$ with surfactant, showing horizontal displacement between curves. 
Compared with nonionic surfactant, cationic surfactant had a greater ability to enhance the activity of all four herbicides tested both in greenhouse and outdoor experiments (Tables 1 and 2). With the exception of herbicides Nos. 2 and 3 in outdoor experiments, cationic surfactant at concentration of $0.1 \%(\mathrm{v} / \mathrm{v})$ and nonionic surfactant at concentration of $0.2 \%(\mathrm{v} / \mathrm{v})$ often had similar effect to improve the effectiveness of other herbicides both in greenhouse and outdoor experiments.

\section{Discussion}

Difference among the surface tension of herbicides may be related to the difference in their formulations. Aliverdi et al. (2009) observed that emulsifiable concentration formulation of clodinafoppropargyl reduced the surface tension of distilled water more than dry flowable formulation of tribenuronmethy. The performance difference in lowering static surface tension by those two surfactants can be ascribed to their physicochemical properties. The tested nonionic $\left[\mathrm{C}_{8} \mathrm{H}_{16} \mathrm{C}_{6} \mathrm{H}_{4}\left(\mathrm{C}_{2} \mathrm{H}_{4} \mathrm{O}\right)_{10} \mathrm{H}\right]$ and cationic $\left[\mathrm{R}-\mathrm{N}\left(\mathrm{C}_{2} \mathrm{H}_{4} \mathrm{O}\right)_{7} \mathrm{H}\left(\mathrm{C}_{2} \mathrm{H}_{4} \mathrm{O}\right)_{8} \mathrm{H}\right]$ surfactants have 10 and 15 ethylene oxide units in their chemical structure, respectively. When the non-ionic (Citogate) and cationic (Frigate) surfactants at both concentrations were added, the lowest and the highest values of surface tension to each herbicide solutions were obtained, respectively (Fig. 1). It is well established by experimental evidence that surfactants containing lower ethylene oxide units were more effective than surfactants containing higher ethylene oxide units in decreasing the static surface tension of spray solutions (Shah et al., 2015). When an additional unit of ethylene oxide is affixed to surfactant structure, it decreases the packing density of hydrophobic groups at interface of water-surfactant, resulting in a reduction in surfactant performance to decrease static surface tension (Myers, 2006).

The data obtained in these experiments indicated that the improvement in efficacy of all herbicides does not depend on the potential of surfactants to reduce surface tension. Citogate (non-ionic surfactant) decreased the surface tension more than Frigate did (cationic surfactant), but Frigate improved the efficacy of herbicides more than Citogate did (Fig. 1 and both Tables). For this reason, the surface tension-lowering ability of surfactant cannot be a proper indicator to select the best surfactant. Therefore, other characteristics of surfactant such as hydrophiliclipophilic balance (HLB) and the characteristics of herbicides such as the logarithm of octanol/water partition coefficient $\left(\log \mathrm{K}_{\mathrm{ow}}\right)$ should be considered to select the best surfactant for a specific herbicide. The HLB can be estimated by observing surfactant dispersion scale in water with no dispersion $=1$ to complete dispersion $=20$ (Rashed-Mohassel et al., 2011). In a static surface tension study, when the nonionic surfactant was added to drinking water, an opaque solution was formed (HLB $\sim 8$ ). When the cationic surfactant was added to drinking water, a clear solution was formed (HLB > 13).

On the other hand, the $\log \mathrm{K}_{\text {ow }}$ of the tested herbicides ranges from 0.7 for iodosulfuron-methylsodium to -1.74 for mesosulfuron-methyl. Previous research (Rashed-Mohassel et al., 2010) showed that surfactants containing higher ethylene oxide units often work best with herbicides with high water solubility (log $\mathrm{K}_{\mathrm{ow}}<1$ ) and surfactants containing lower ethylene oxide units often work best with herbicides with low water solubility $\left(\log \mathrm{K}_{\mathrm{ow}}>1\right)$. Therefore, the results of the present research along with previous researches supported the hypothesis that effectiveness of a lipophilic herbicide is improved by adding a surfactant with lower ethylene oxide content, whereas effectiveness of a hydrophilic herbicide is enhanced by adding a surfactant with higher ethylene oxide content (Shah et al., 2015).

\section{Conclusion}

We concluded that the surface tension-lowering ability of surfactant is not always a proper indicator to select a better one, but could be an effective factor. The results confirm the idea that the hydrophilic-lipophilic balance (HLB) value can help to select the type of surfactant that is appropriate for a given herbicide. Thus, high-HLB surfactant will be more suitable for watersoluble herbicides than low-HLB surfactant. As judged by the data obtained, the tested cationic surfactant with a high-HLB value was more effective to enhance the activity of four herbicides tested with a logarithm of octanol/water partition coefficient $\log \mathrm{K}_{\mathrm{ow}}<1$, although the tested nonionic surfactant with a low-HLB value was more effective at lowering the surface tension of all spray solutions. Therefore, our recommendation for choosing the best surfactant for a given application is to use the HLB system.

\section{Acknowledgments}

This work was supported by the Ferdowsi University of Mashhad, Iran through the RESEARCH program (Project No. 2/17494). The authors wish to acknowledge hereby.

Received 27022016

Accepted 26072016

\section{References}

Aliverdi A., Rashed-Mohassel M. H., Zand E., NassiriMahallati M. 2009. Increased foliar activity of clodinafoppropargyl and/or tribenuron-methyl by surfactants and their synergistic action on wild oat (Avena ludoviciana) and wild mustard (Sinapis arvensis). Weed Biology and Management, 9 (4): 292-299 http://dx.doi.org/10.1111/j.1445-6664.2009.00353.x

Chhokar R. S., Sharma R. K., Sharma I. 2012. Weed management strategies in wheat - a review. Journal of Wheat Research, 4 (2): $1-21$ 
Deihimfard R., Zand E., Damghani A. M., Soufizadeh S. 2007. Herbicide risk assessment during the wheat selfsufficiency project in Iran. Pest Management Science, 63 (10): 1036-1045 http://dx.doi.org/10.1002/ps.1432

Dickinson R., Royer F. 2014. Weeds of North America, 656 p. http://dx.doi.org/10.7208/chicago/9780226076584.001.0001

Gerkhloo J., Mazaheri D., Ghanbari A., Ghanadha M. R. 2007. Evaluation of economic threshold of weeds in wheat. Iranian Journal of Agricultural Sciences, 36 (1): 429-1435 (in Persian)

Gitsopoulos T. K. I, Damalas C. A., Georgoulas I. 2014. Improving diquat efficacy on grasses by adding adjuvants to the spray solution before use. Planta Daninha, $32(2): 355-360$ http://dx.doi.org/10.1590/S0100-83582014000200013

Green J. M. 2007. Review of glyphosate and ALS-inhibiting herbicide crop resistance and resistant weed management. Weed Technology, 21 (2): 547-558 http://dx.doi.org/10.1614/WT-06-004.1

Hesammi E. 2011. Different densities of weeds and wild oats (Avena ludoviciana) and canary grass (Phalaris minor) on yield and yield components of wheat cultivar Chamran. Advances in Environment Biology, 5 (8): 2497-2500

Kammler K. J., Alan-Walters S., Young B. G. 2010. Effects of adjuvants, halosulfuron, and grass herbicides on Cucurbita spp. injury and grass control. Weed Technology, 24 (2): 147-152 http://dx.doi.org/10.1614/WT-D-09-00015.1

Kashani F. B., Zand E., Alizadeh H. M. 2007. Study on diclofop-methyl resistance in wild oat (Avena ludoviciana Durieu.): a comparison between the whole plant and seed bioassay. Pakistan Journal of Weed Science Research, 13 (1-2): 69-81

Knezevic S. Z., Datta A., Scott J., Charvat L. D. 2009. Adjuvants influenced saflufenacil efficacy on fall-emerging weeds. Weed Technology, 23 (3): 340-345 http://dx.doi.org/10.1614/WT-08-174.1

Kudsk P. 2008. Optimising herbicide dose: a straightforward approach to reduce the risk of side effects of herbicides. Environmentalist, 28 (1): 49-55 http://dx.doi.org/10.1007/s10669-007-9041-8

Kudsk P., Mathiassen S. K. 2007. Analysis of adjuvant effects and their interactions with variable application parameters. Crop Protection, 26 (3): 328-334 http://dx.doi.org/10.1016/j.cropro.2005.06.012

Loken J.R., Hatterman-Valenti H.M. 2013. Early-season weed control using herbicides with adjuvants in direct-seeded onion. Weed Technology, 27 (2): 369-372 http://dx.doi.org/10.1614/WT-D-12-00157.1

McCullough P. E., Hart S. E. 2009. Chlelated iron and adjuvants influence bispyribac-sodium efficacy for annual bluegrass (Pоа аппиа) control in cool-season turfgrasses. Weed Technology, 23 (4): 519-523 http://dx.doi.org/10.1614/WT-09-027.1

McDougall S. 2012. Water quality for chemical spraying. Department of Primary Industries, State of New South Wales, Australia, p. 1-5

Montazeri M. 2007. Influence of winter wild oat (Avena ludoviciana), annual canary grass (Phalaris minor) and wild mustard (Sinapis arvensis) at different density on yield and yield component of wheat. Pajouhesh-va-Sazandegi, 74 (1): 72-78 (in Persian)
Myers D. 2006. Surfactant science and technology ( $3^{\text {rd }}$ ed.)

Rao V. S. 2015. Transgenic herbicide resistance in plantss

Rashed-Mohassel M. H., Aliverdi A., Hammami H., Zand E. 2010. Optimizing the performance of diclofop-methyl, cycloxydim, and clodinafop-propargyl on littleseed canarygrass (Phalaris minor) and wild oat (Avena ludoviciana) control with adjuvants. Weed Biology and Management, 10 (1): 57-63 http://dx.doi.org/10.1111/j.1445-6664.2010.00367.x

Rashed-Mohassel M. H., Aliverdi A., Rahimi S. 2011. Optimizing dosage of sethoxydim and fenoxaprop-p-ethyl with adjuvants to control wild oat. Industrial Crops and Products, 34 (3): 1583-1587 http://dx.doi.org/10.1016/j.indcrop.2011.05.023

Shah V., Bharatiya B., Shah D. O., Mukherjee T. 2015. Correlation of dynamic surface tension with sedimentation of PTFE particles and water penetration in powders. Langmuir, 31 (51): 13725-13733 http://dx.doi.org/10.1021/acs.langmuir.5b03725

Stagnari F., Chiarini M., Pisante M. 2007. Influence of fluorinated surfactants on the efficacy of some postemergence sulfonylurea herbicides. Pesticide Science, 32 (1): $16-23$ http://dx.doi.org/10.1584/jpestics.G06-29

Vanhanen J., Hyvarinen A. P., Anttila T., Viisanen Y., Lihavainen H. 2008. Ternary solution of sodium chloride, succinic acid and water surface tension and its influence on cloud droplet activation. Atmospheric Chemistry and Physics, 8 (16): 4595-4604 http://dx.doi.org/10.5194/acp-8-4595-2008

Zand E., Kashani F. B., Baghestani M. A., Maknali A., Minbashi M., Soufizadeh S., Deihimfard R. 2007. Investigating the distribution of clodinafop-propargyl resistant wild oat (Avena ludoviciana) populations in South Western Iran. Environmental Science, 4 (4): 85-92

Zand E., Baghestani M. A., Alikhani M. A., Soufizadeh S., Khayami M. M., Pourazar R., Sabeti P., Jamali M., Bagherani N., Forouzesh S. 2010. Chemical control of weeds in wheat (Triticum aestivum L.) in Iran. Crop Protection, 29 (11): 1223-1231 http://dx.doi.org/10.1016/j.cropro.2010.07.004 
ISSN 1392-3196 / e-ISSN 2335-8947

Zemdirbyste-Agriculture, vol. 103, No. 3 (2016), p. 289-296

DOI $10.13080 /$ z-a.2016.103.037

\title{
Katijioninių ir nejoninių paviršiaus aktyviụjų medžiagų poveikis ALS inhibitorių herbicidų efektyvumui nuo Avena sterilis
}

\author{
A. Aliverdi ${ }^{1}$, H. Hammami² \\ ${ }^{1} \mathrm{Bu}$-Ali Sina universiteto Agronomijos ir augalų selekcijos fakultetas, Iranas \\ ${ }^{2}$ Birjand universiteto Agronomijos ir augalų selekcijos fakultetas, Iranas
}

\section{Santrauka}

Kiekvienam herbicidui sunku parinkti tinkamą paviršiaus aktyviają medžiagą. Siekiant nustatyti, ar būtų galima pagerinti keturių acetolaktato sintazès (ALS) inhibitorių herbicidų efektyvumą nuo Avena sterilis naudojant dvi paviršiaus aktyviąsias medžiagas ir dvi jų normas, $2013 \mathrm{~m}$. Irano Ferdowsi Mashhad universitete šiltnamio ir lauko sąlygomis buvo atlikti keli eksperimentai. Abi paviršiaus aktyviosios medžiagos buvo efektyvios mažinant visų herbicidų tirpalų paviršiaus įtemptị, tačiau nejoninė paviršiaus aktyvioji medžiaga buvo efektyvesnè nei katijoninè. Pagal efektyviosios dozès vertes ALS inhibitorių herbicidai, naudoti nuo A. sterilis, išsidèstè taip: sulfosulfuronas $>$ metilmezosulfuronas + metiljodosulfuronas ir natris su apsaugine medžiaga mefenpiru $>$ metilmezosulfuronas + metiljodosulfuronas ir natris su apsaugine medžiaga mefenpirdietilu $>$ metilmetsulfuronas + sulfosulfuronas. Visų herbicidų efektyviosios dozès vertès sumažèjo pridèjus paviršiaus aktyviujų medžiagų. Tirtų herbicidų efektyvumą labiau didino katijoninès paviršiaus medžiagos nei nejoninès.

Reikšminiai žodžiai: dozès poveikis, herbicidų efektyvumas, sulfonilurèjos grupès herbicidai.

Please use the following format when citing the article:

Aliverdi A., Hammami H. The effect of cationic and nonionic surfactants on the efficacy of ALS-inhibitor herbicides against Avena sterilis. Zemdirbyste-Agriculture, 103 (3): 289-296 DOI 10.13080/z-a.2016.103.037 